\title{
Remedia Sternutatoria over the Centuries: TRP Mediation
}

\author{
Lujain Aloum ${ }^{1}\left(\mathbb{D}\right.$, Eman Alefishat ${ }^{1,2,3} \mathbb{0}$, Janah Shaya ${ }^{4}\left(\mathbb{D}\right.$ and Georg A. Petroianu ${ }^{1, *}$ \\ 1 Department of Pharmacology, College of Medicine and Health Sciences, Khalifa University of Science and \\ Technology, Abu Dhabi 127788, United Arab Emirates; lujain.aloum@ku.ac.ae (L.A.); \\ Eman.alefishat@ku.ac.ae (E.A.) \\ 2 Center for Biotechnology, Khalifa University of Science and Technology, Abu Dhabi 127788, \\ United Arab Emirates \\ 3 Department of Biopharmaceutics and Clinical Pharmacy, Faculty of Pharmacy, The University of Jordan, \\ Amman 11941, Jordan \\ 4 Pre-Medicine Bridge Program, College of Medicine and Health Sciences, Khalifa University of Science and \\ Technology, Abu Dhabi 127788, United Arab Emirates; shaya.janah@ku.ac.ae \\ * Correspondence: georg.petroianu@ku.ac.ae; Tel.: +971-50-413-4525
}

Citation: Aloum, L.; Alefishat, E.; Shaya, J.; Petroianu, G.A. Remedia Sternutatoria over the Centuries: TRP Mediation. Molecules 2021, 26, 1627. https://doi.org/10.3390/molecules 26061627

Academic Editor: Christian Salles

Received: 18 February 2021

Accepted: 5 March 2021

Published: 15 March 2021

Publisher's Note: MDPI stays neutral with regard to jurisdictional claims in published maps and institutional affiliations.

Copyright: (C) 2021 by the authors. Licensee MDPI, Basel, Switzerland. This article is an open access article distributed under the terms and conditions of the Creative Commons Attribution (CC BY) license (https:/ / creativecommons.org/licenses/by/ $4.0 /)$.

\begin{abstract}
Sneezing (sternutatio) is a poorly understood polysynaptic physiologic reflex phenomenon. Sneezing has exerted a strange fascination on humans throughout history, and induced sneezing was widely used by physicians for therapeutic purposes, on the assumption that sneezing eliminates noxious factors from the body, mainly from the head. The present contribution examines the various mixtures used for inducing sneezes (remedia sternutatoria) over the centuries. The majority of the constituents of the sneeze-inducing remedies are modulators of transient receptor potential (TRP) channels. The TRP channel superfamily consists of large heterogeneous groups of channels that play numerous physiological roles such as thermosensation, chemosensation, osmosensation and mechanosensation. Sneezing is associated with the activation of the wasabi receptor, (TRPA1), typical ligand is allyl isothiocyanate and the hot chili pepper receptor, (TRPV1), typical agonist is capsaicin, in the vagal sensory nerve terminals, activated by noxious stimulants.
\end{abstract}

Keywords: sternutation; transient receptor potential (TRP); sneezing; agonist

\section{Introduction}

When we sneeze (sternutatio), one of the upper airway reflexes, starting with a deep inspiration proceeded by involuntary expulsion of air [1]. The reflex is mediated by the vagal afferent input from the nasal receptors [2,3]. Transient receptor potential (TRP) channels have been reported to play a role in sneezing as nasal receptors [4]. The TRP channel superfamily consists of 28-cation channels divided into six subfamilies. The TRPA1 (ankyrin subfamily, member 1) is known as the wasabi receptor (typical ligand is allyl isothiocyanate, the main pungent compound of wasabi) and the TRPV1 (vanilloid subfamily, member 1) is known as the hot chili pepper receptor (typical ligand is capsaicin, the pungent compound of hot chili pepper) [5-8]. TRPA1 and TRPV1 have been associated with sneezing [4].

Subsequent to the excitation of receptors in the nasal mucous membranes, sensory information is transmitted mainly via the nasopalatine nerve (branch of the maxillary nerve; NC V2), while accompanying parasympathetic afferent fibers run to the pterygopalatine ganglion, and then to the superior salivatory nucleus. A putative sneezing center in the medulla is activated and a complex motor pattern is initiated: a deep inspiration is triggered, accompanied by the head tilting to the back, eye closure and nasopharyngeal and glottis closure. The airway closure allows for the intrathoracic pressure to build up following contraction of the expiratory muscles, which is followed by head tilting to the front, glottis opening and an explosive expulsion of air from the lungs (hopefully of the noxious stimulus) $[9,10]$. 
Sneezing had great significance and value throughout history; it exerted a strange fascination on humans. Despite the fact that, during the Middle Ages, sneezing was a threat due to the spread of the Plague disease, sneezing was generally seen as a positive reflex throughout history [11]. Induced sneezing was widely used by physicians for therapeutic purposes, on the assumption that sneezing eliminates noxious factors from the body, mainly from the head. Sneezing protects the upper airway and efficiently clears the nose and nasopharynx [1]. The Greek philosophers from the fourth century BC depicted sneezing as a divine sign. Hippocrates said that sneezing is helpful to diseases, except in the setting of pulmonary illnesses. In Pagan culture, sneezing was considered to expel the devil from the human body. Furthermore, Celsus considered sneezing an important part of disease recovery [11]. The Romans and Greeks depicted sneezing as an indication of well-being [10].

Physicians over the centuries utilized intranasal powders/mixtures to induce sneezing. In this review, we explored various mixtures and their constituents, used as remedia sternutatoria (or sneeze-inducing) over the centuries, aiming to conclude the mechanism of action via which these remedies trigger sneezing.

\section{Remedia Sternutatoria: Terminology}

The various sneeze-inducing powders are named Errhina, Ptarmica or Sternutatoria (remedia). Errhina (into the nose) are substances which, if snuffed up the nose, promote a discharge of mucus from that organ, and can induce occasional sneezing. The name Ptarmica comes from the Greek word ptairo (to sneeze) and means "causes sneezing", as such, it is a synonym of the Latin sternutatoria, or a remedy that excites sneezing [12]. Parr (1819) stated that very little difference appears between the different articles that constitute this class, with the exception of their strength. Betony, sweet marjoram, the orris root, and rosemary tops are of the milder kind (Errhina), while asarum, euphorbium, tobacco, white hellebore, and the turbith mineral are of the stronger kind (Remedia sternutatoria) [13].

\section{Remedia Sternutatoria: Main Active Components}

Table 1 lists the various herbs and natural remedies used by numerous physicians over the centuries to induce sneezing. 
Table 1. Herbs and natural remedies used by various physicians over the centuries to induce sneezing.

\begin{tabular}{|c|c|c|c|c|c|c|c|c|c|c|c|c|c|c|c|c|c|}
\hline \multirow[b]{2}{*}{$\begin{array}{c}\text { Name as } \\
\text { Reported over } \\
\text { History }\end{array}$} & \multirow[b]{2}{*}{ Current Name } & \multicolumn{16}{|c|}{ Physicians } \\
\hline & & $\begin{array}{l}\text { Pedanius } \\
(\sim 40-90)\end{array}$ & $\begin{array}{l}\text { Aëtius } \\
(\approx+574)\end{array}$ & $\begin{array}{c}\begin{array}{c}\text { De } \\
\text { Gordon } \\
(1270- \\
1330)\end{array} \\
\end{array}$ & $\begin{array}{c}\text { De } \\
\text { Montagna } \\
(1400- \\
1460)\end{array}$ & $\begin{array}{l}\text { Fuchs } \\
\text { (1501- } \\
1566)\end{array}$ & $\begin{array}{l}\text { Dalla } \\
\text { Croce } \\
(1509- \\
1575)\end{array}$ & $\begin{array}{l}\text { Joel } \\
(1510- \\
1579)\end{array}$ & $\begin{array}{c}\text { Joubert } \\
(1529- \\
1582)\end{array}$ & $\begin{array}{c}\text { Zacuth } \\
\text { (1575- } \\
1642)\end{array}$ & $\begin{array}{l}\text { Chalmeteus } \\
(\sim 1560:)\end{array}$ & $\begin{array}{l}\text { Schoock } \\
\text { (1614- } \\
1669)\end{array}$ & $\begin{array}{l}\text { Woyt } \\
\text { (1671- } \\
1709)\end{array}$ & $\begin{array}{l}\text { Andrioli } \\
\text { (1672- } \\
\text { 1713) }\end{array}$ & $\begin{array}{c}\text { Arnemann } \\
\quad(1763- \\
1806)\end{array}$ & $\begin{array}{l}\text { Par } \\
(1750- \\
1810)\end{array}$ & $\begin{array}{l}\text { Hesselbach } \\
\text { (1788- } \\
\text { 1856) }\end{array}$ \\
\hline Cumini & $\begin{array}{l}\text { Cuminum } \\
\text { cyminum }\end{array}$ & & $x$ & & & $x$ & & & & & & & & & & & \\
\hline Piperis & Piper nigrum & & $x$ & $x$ & $x$ & $x$ & $x$ & $x$ & $x$ & $x$ & $x$ & $x$ & & & & & \\
\hline $\begin{array}{c}\text { Herba cas- } \\
\text { torii//castoreum }\end{array}$ & Castoreum & $\mathrm{x}$ & $\mathrm{x}$ & $x$ & & $x$ & $x$ & $x$ & & $x$ & & $x$ & $x$ & & & & \\
\hline Ptarmice & Achillea ptarmica & $x$ & & & & $x$ & & & & & & $x$ & & & & & \\
\hline Nicotianae & Tobacco leaves & & & & & & & & & $x$ & & & $x$ & $x$ & $x$ & $x$ & \\
\hline $\begin{array}{l}\text { Ocimum } \\
\text { basilicum }\end{array}$ & $\begin{array}{l}\text { Ocimum } \\
\text { basilicum }\end{array}$ & $x$ & & & & & & & & & & & & & & & \\
\hline Cariophlli & Caryophylli flos & & & & & & & & & & & $x$ & & & & & \\
\hline Sinapis & & $x$ & & & & & & & & & & $x$ & & & & & \\
\hline Urtica & Urtica dioica & & & & $x$ & & & & & & & & & & & & \\
\hline Cardamom & $\begin{array}{c}\text { Elettaria } \\
\text { cardamomum }\end{array}$ & & & & & & & & $x$ & & & & & & & & \\
\hline $\begin{array}{l}\text { Aframomum- } \\
\text { Grana } \\
\text { paradise }\end{array}$ & $\begin{array}{l}\text { Aframomum } \\
\text { melegueta }\end{array}$ & & & & & & & & & & & & & & & & \\
\hline Ginger & Zingiber officinale & & & & $x$ & & & & $x$ & & & & & & & & \\
\hline Galangal & & & & & $x$ & & & & $x$ & & & & & & & & \\
\hline Coriander & $\begin{array}{l}\text { Coriandrum } \\
\text { sativum }\end{array}$ & & & & & & & & & & & & $x$ & & & & \\
\hline $\begin{array}{l}\text { Salt liquorice- } \\
\text { Salzlakritz }\end{array}$ & $\begin{array}{l}\text { Glycyrrhiza } \\
\text { glabra }\end{array}$ & & & & & & & & & & & & $\mathrm{x}$ & & & & \\
\hline Paeoniae & & & & & & & & & & $x$ & & & & & & & \\
\hline Myrrhae & $\begin{array}{l}\text { Commiphora } \\
\text { myrrha }\end{array}$ & & & & & & & & & $x$ & & & & & & & \\
\hline Kampfer & Camphor & & & & & & & & & & & & & & $x$ & & \\
\hline Asarum & & & & & & & & & & & & & & & & $x$ & $x$ \\
\hline $\begin{array}{c}\text { Nigella } \\
\text { damascena }\end{array}$ & $\begin{array}{c}\text { Nigella } \\
\text { damascena }\end{array}$ & & & & & & & & & & & & $x$ & & & & \\
\hline
\end{tabular}


Table 1. Cont.

\begin{tabular}{|c|c|c|c|c|c|c|c|c|c|c|c|c|c|c|c|c|c|}
\hline \multirow[b]{2}{*}{$\begin{array}{c}\text { Name as } \\
\text { Reported over } \\
\text { History }\end{array}$} & \multirow[b]{2}{*}{ Current Name } & \multicolumn{16}{|c|}{ Physicians } \\
\hline & & $\begin{array}{l}\text { Pedanius } \\
(\sim 40-90)\end{array}$ & $\begin{array}{l}\text { Aëtius } \\
(\approx 5574)\end{array}$ & $\begin{array}{c}\begin{array}{c}\text { De } \\
\text { Gordon } \\
(1270-\end{array} \\
1330)\end{array}$ & $\begin{array}{c}\text { De } \\
\text { Montagna } \\
(1400- \\
1460)\end{array}$ & $\begin{array}{l}\text { Fuchs } \\
\text { (1501- } \\
1566)\end{array}$ & $\begin{array}{l}\text { Dalla } \\
\text { Croce } \\
(1509- \\
1575)\end{array}$ & $\begin{array}{c}\text { Joel } \\
\text { (1510- } \\
1579)\end{array}$ & $\begin{array}{c}\text { Joubert } \\
(1529- \\
1582)\end{array}$ & $\begin{array}{c}\text { Zacuth } \\
\text { (1575- } \\
1642)\end{array}$ & $\begin{array}{l}\text { Chalmeteus } \\
(\sim 1560:)\end{array}$ & $\begin{array}{l}\text { Schoock } \\
(1614- \\
1669)\end{array}$ & $\begin{array}{l}\text { Woyt } \\
\text { (1671- } \\
1709)\end{array}$ & $\begin{array}{c}\text { Andrioli } \\
\text { (1672- } \\
1713)\end{array}$ & $\begin{array}{c}\text { Arnemann } \\
\quad(1763- \\
1806)\end{array}$ & $\begin{array}{l}\text { Par } \\
(1750- \\
1810)\end{array}$ & $\begin{array}{c}\text { Hesselbach } \\
\quad \text { (1788- } \\
\text { 1856) }\end{array}$ \\
\hline Cyclamini & & & $x$ & & & $x$ & & & & & & & & & & & \\
\hline Elleboro albo & Veratrum album & & & $x$ & $x$ & $x$ & $x$ & $x$ & $x$ & $\mathrm{x}$ & $x$ & $x$ & $x$ & $x$ & $x$ & $x$ & $x$ \\
\hline $\begin{array}{l}\text { Daphnoides- } \\
\text { Spurge } \\
\text { Laurel }\end{array}$ & Daphne laureola & $x$ & & & & & & & & & & & & & & & \\
\hline Pyrethri & & & & & & & $x$ & & & & $x$ & $x$ & & $x$ & & & \\
\hline $\begin{array}{l}\text { Mercurius } \\
\text { dulcis }\end{array}$ & $\begin{array}{c}\text { Hydrargyrum } \\
\text { chloratum dulce }\end{array}$ & & & & & & & & & & & & & & $x$ & & \\
\hline Chinapuder & China powder & & & & & & & & & & & & & & $x$ & & \\
\hline Nitro & Saltpeter & & & & & $x$ & & & & & & & & & & & \\
\hline Aloe & & & & & & & & & & $x$ & & & & & $x$ & & \\
\hline Herba lanaria & $\begin{array}{l}\text { Saponaria } \\
\text { officinalis }\end{array}$ & $\mathrm{x}$ & $\mathrm{x}$ & & & $x$ & & & & & & & & & & & \\
\hline
\end{tabular}

- Pedanius Dioscorides (c. 40-90 AD) was a Greek physician, pharmacologist, botanist, and author of a multivolume encyclopedia of herbal medicine [14].

Aëtius of Amida ( $\approx+574)$ was a Greek physician at the court of Byzantine Emperor Justinian [15].

Gordon, Bernard de (1270-1330) was a French physician teacher; his books, specifically Lilium medicinae, formed an important part of the medical curriculum of medieval Europe [16].

- De Montagna, Bartholomaeus (ca. 1400-ca. 1460) was an Italian physician and professor in Padua and Bologna.

- Fuchs, Leonhard (1501-1566) was a German physician and botanist; professor of medicine and Chancellor of the University of Tübingen in Württemberg, Germany [17,18]

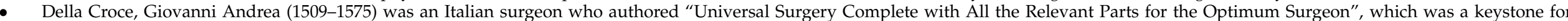
traumatology [18].

- Joel, Franciscus primus (Joó Ferenc; 1510-1579) was a Hungarian-born pharmacist and physician, professor, and then, the rector of the University in Greifswald, Duchy of Pomerania [19]

- Joubert, Laurent (1529-1582) was the Chancellor of the Faculty of Medicine at the University of Montpellier [20]

- Zacuth, Abraham (1575-1642) was famous for his precise descriptions of diseases, such as the plague and blackwater fever [21]

- Chalmeteus, Antonius (Antoine Chaumette) was a French surgeon who authored "Enchiridion chirurgicum, externorum morborum remedia complectens" [22].

- Schoock, Martin (1614-1669) was a Dutch historian and professor at the University of Deventer and the University of Frankfurt (Oder) [23].

Woyt, Johann Jacob (1671-1709) was a German physician and professor of medicine at the University of Königsberg (Prussian city that is now Kaliningrad, Russia) [24].

- Arnemann, Justus (1763-1806) was a German surgeon and professor of medicine at the University of Göttingen [25].

- Parr, Bartholomew (1750-1810) was a British surgeon and Fellow of the Royal Society of Edinburgh and London [26]

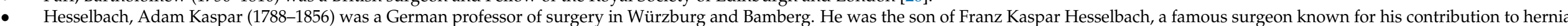
surgeries [27]. 
Cumini or Cuminum cyminum (cumin) is a popular hot spice in many parts of the world; the ancient Greeks apparently kept cumin at the dining table in its own container, and this practice continues in parts of North Africa. In medieval Europe, cumin was used as a cheap(er) substitute for black pepper [28]. Legrand and his colleagues found that cuminal, the main active ingredient of cumin [29], specifically activates TRPA1 channels without affecting TRPV1 [30].

Piperis or Piper nigrum (black pepper), the source plant of both black and white pepper, contains the main active constituent alkaloid piperine [31,32]. Piperine activates TRPV1 [33,34], where it was found to bind to the same binding pocket as capsaicin [35]. Capsaicin (a vanilloid), the active component found in chili powder (Capsicum) and cayenne pepper, is the typical agonist of TRPV1 [36]. Dong et al. revealed that threonine 671 (T671) found on the pore-forming S6 segment is a vital site for the piperine-induced activation of TRPV1. It is assumed that piperine directly interacts with the S6 segment to facilitate the opening of the channel [35]. Furthermore, the piperidine ring, proposed to be important for TRPV1 activity as its replacement with $N, N$-diisobutyl, eliminated TRPV1 interactions [37]. Other studies found that piperine and its analogs activate not only TRPV1, but also TRPA1 [38,39]. The half-maximal effective concentration (EC50) of piperine for TRPV1 and TRPA1 was found to be 250 and 58 times higher than capsaicin and allyl isothiocyanate (a typical agonist of TRPA1), respectively [38].

Herba castorii, despite its name (herba; wort), is not a plant, but rather a castoreum (Bibergeil), the yellowish exudate from the castor sacs of the mature beaver [40]. In particular, 1,2-dihydroxybenzene (catechol) (Figure 1A), 4-ethylphenol (Figure 1B), acetophenone and 3-hydroxyacetophenone (Figure 1C) are four compounds with the strongest pheromonal activity in castoreum [41]. It was found that catechol estrogens positively regulated TRPA1 activity [42]. Acetophenone was found to be a weak agonist of TRPA1 [43].

A

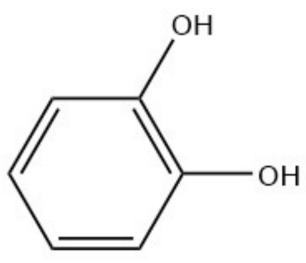

B

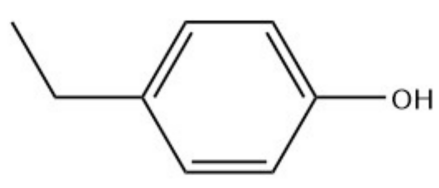

C

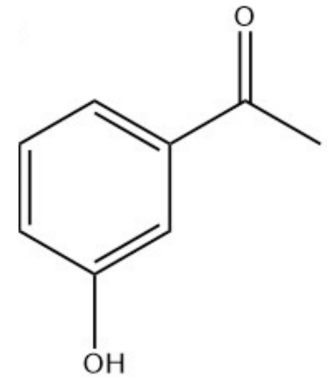

Figure 1. Chemical structures of (A) catechol, (B) 4-ethylphenol and (C) 3-hydroxyacetophenone.

Some Euphorbio plants (specifically Euphorbia resinifera) contain resiniferatoxin, a (3-4 orders of magnitude) more potent, functional analog of capsaicin. It causes severe burning pain in sub-microgram quantities when ingested orally [44]. Resiniferatoxin has been used in several studies for its ability to activate TRPV1 [45-47].

Achillea ptarmica: the name ptarrmica comes from the Greek word ptairo (sneeze), while achillea is related to the hero's heel and the belief that the plant can heal wounds. The colloquial Italian name of the plant is sternutella, while in English it is called sneezewort. It is assumed that alkyl-amides are responsible for most pharmacological actions of the Achillea ptarmica [48]. Pellitorine (a trans isomer) and 8,9-Z-dehydropellitorine (Figure 2) are the main alkamides of Achillea ptarmica [48,49]. Trans-Pellitorine, an aliphatic alkylamide analogue of capsaicin, is reported to activate TRPV1 and TRPA1 channels; however, recent studies have found that this is mediated indirectly, possibly via the downstream signaling of an unknown molecular target [50,51]. On the contrary, Pellitorine, extracted from Tetradium daniellii, was found to be an antagonist at the TRPV1 channel [52]. 


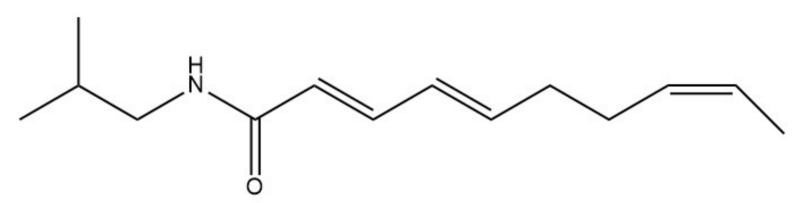

Figure 2. Chemical structure of 8,9-Z-dehydropellitorine.

Nicotianae species are recognized as tobacco plants. Snuff is made from finely ground tobacco leaves. When applied locally, nicotine often causes a sneeze [53]. The main alkaloid in tobacco is nicotine [54]. Nicotine demonstrated a bimodal effect on TRPA1 channels, in which low and high concentrations resulted in the activation and inhibition of the channel, respectively [55,56], similar to the effect at nicotinic cholinergic receptors [57]. Notably, Talavera showed that the TRPA1 channel regulates the nicotine-induced nasal irritating effect rather than nicotinic cholinergic receptors [55]. Furthermore, the TRPV1 response to capsaicin was found to be sensitized by nicotine [58]; however, a later study found that nicotine-inhibited TRPV1 [55].

Ocimum basilicum oil comprises eugenol and methyl chavicol (Figure 3A) as the main constituents [59]. Eugenol, beta-caryophyllene (Figure 3B) and eugenyl acetate (Figure 3C) are the chief active ingredients in Caryophylli flos, recognized as cloves [60]. It was found that eugenol activates TRPA1 [61-63] and TRPV1 [64,65].<smiles>C=CCc1ccc(OC)cc1</smiles><smiles>C=C1CC/C=C(/C)CCC2C1CC2(C)C</smiles>

$\mathrm{C}$<smiles>C=CCc1ccc(OC(C)=O)c(OC)c1</smiles>

Figure 3. Chemical structures of (A) methyl chavicol, (B) beta-caryophyllene and (C) eugenyl acetate.

Sinapis alba (white or yellow mustard) and Sinapis nigra (black mustard) both contain the active component, allyl isothiocyanate, which is one of the main ingredients accountable for the mustard taste $[66,67]$. Allyl isothiocyanate is produced when the sinapis plant is processed (e.g., crushed), allowing myrosinase isoenzymes to convert sinalbin and sinigrin, in Sinapis alba and Sinapis nigra, respectively, into allyl isothiocyanate [66,68]. Allyl isothiocyanate constitutes approximately $70 \%$ of the mustard seed essential oil [69]. Not only is allyl isocyanate the typical agonist of TRPA1 [61,70], but also it exerts an inhibitory effect on TRPA1 at high concentrations (millimolar), suggesting bimodal activity [71]. Furthermore, this compound was recently found to activate TRPV1 channels with approximately 10-100-fold higher concentrations compared to capsaicin [71-73]. Mustard oil is considered a partial agonist of TRPV1. Furthermore, it was shown that mustard oil causes fast desensitization of TRPA1, but not TRPV1 [71].

Urtica dioica $\mathrm{L}$. is commonly recognized as "stinging nettle". The main constituent of its essential oil is carvacrol [74]. Carvacol is reported to activate and desensitize TRPA1 [75-78].

Ranunculus contains the main active component aconitine (Figure 4). Aconitine has been shown to antagonize TRPV1 channels, exerting mixed competitive and noncompetitive allosteric regulation [79].

Cardamom (Elettaria cardamomum) contains 1,8-cineole as one of the main active constituents [80]. This bicyclic monoterpenoid has been shown to activate TRPA1, but not TRPV1 channels [81]. In contrast, Takaishi and his colleagues reported that 1,8-cineole is a natural antagonist of human TRPA1 channels [82]. This bimodal action has been reported with menthol, in which the activity at the mouse TRPA1 was concentration dependent; it was an agonist at low concentrations and an antagonist at higher concentrations [83]. 


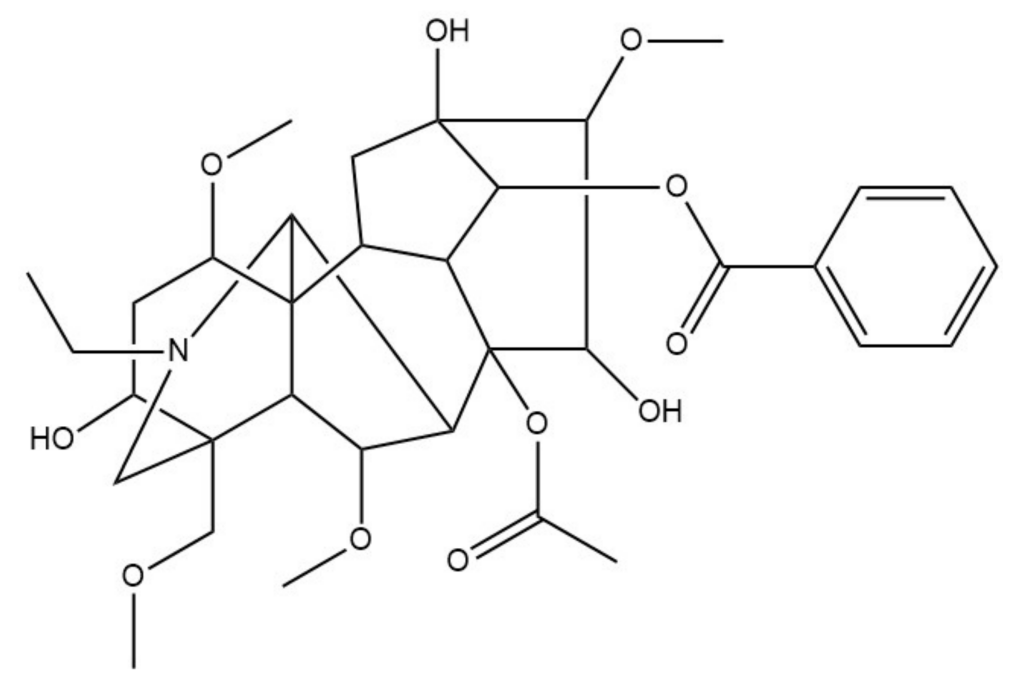

Figure 4. Chemical structure of aconitine.

Aframomum melegueta, commonly known as grain of paradise or guinea grains, contains rich amounts of 6-paradol, 6-gingerol, 6-shogaol and other pungent compounds. The main components of ginger extract are 6-gingerol and 6-shogaol [84]. Other studies found that 6-paradol is also one of the main components [85]. These compounds have been shown to activate TRPV1 [86-88] and TRPA1 [61,88,89].

Galangal, reported over history, is most probably in reference to either greater galangal (Alpinia galanga) or lesser galangal (Alpinia officinarum) or black galangal (Kaempferia galangal). The key pungent compound of Alpinia galanga, $1^{\prime}$-acetoxychavicol acetate, was found to activate TRPA1 in HEK cells; it expressed those receptors, but did not activate TRPV1. Notably, 1'-acetoxychavicol acetate showed higher potency (3.8-fold lower EC50) than the usual TRPA1 agonist (allyl isothiocyanate) [90]. Several compounds have been isolated from Alpinia officinarum; galangal appears to be the principal component in various parts of the plant, such as the leaves, rhizomes and aerial parts [91,92]. Galangal was found to activate TRPA1 at low micromolar concentrations without affecting TRPV1 [92]. Several major components of the essential oil of Kaempferia galangal have been reported with ethyl trans- $p$-methoxycinnamate (most abundant, Figure 5), 1,8-cineole, etc. [93]. The latter was found to activate TRPA1 channels [81].<smiles>CCOC(=O)/C=C/c1ccc(OC)cc1</smiles>

Figure 5. Chemical structure of ethyl trans-p-methoxycinnamate.

Coriander (Coriandrum sativum) essential oil composition differs in proportion depending on environmental conditions. However, linalool was consistently found to be the most abundant constituent [94,95], which activates TRPA1 without affecting TRPV1 [88,96].

The roots of liquorice (Glycyrrhiza glabra) contain the chief active component glycyrrhizin, (Figure 6) which can be hydrolyzed to glycyrrhetinic acid in the human body [97]. The latter was found to activate TRPA1 [98]. 


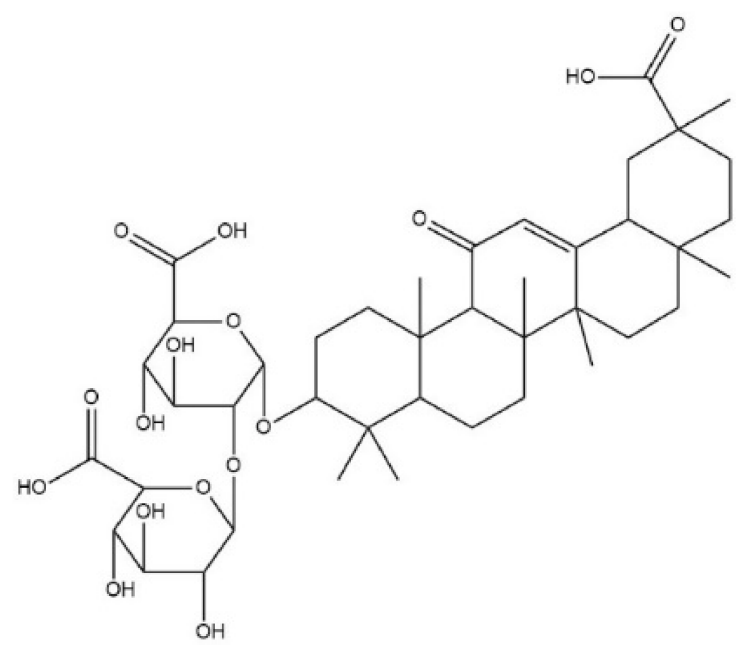

Figure 6. Chemical structure of glycyrrhizin.

Paeoniae (genus) includes paeoniflorin (monoterpene glycoside) as the main active component (Figure 7) $[99,100]$. It has been reported to exert inhibitory activity against TRPV1 expression and TRPV1-mediated effects [101].

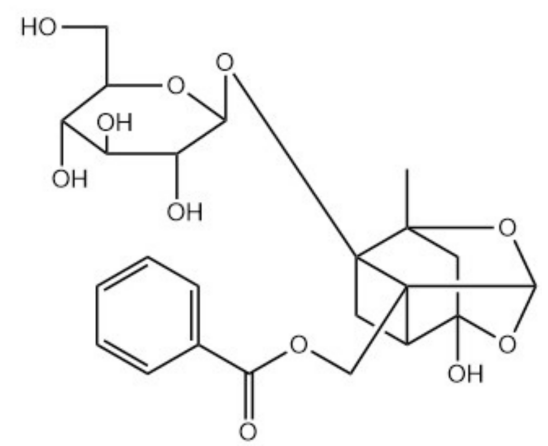

Figure 7. Chemical structure of paeoniflorin.

Myrrh contains volatile oil, resin, gum and a bitter component [102]. Curzerene is the most abundant constituent of the essential oil obtained from the oleo-gum resin of Commiphora myrrha [103]. The water extract of frankincense and myrrh was found to inhibit TRPV1 [104].

Camphor is a volatile, terpenoid ketone. It can either be obtained from the wood of the camphor tree (Cinnamomum camphora) or it can be chemically synthesized from turpentine [105]. Camphor was found to activate and desensitize TRPV1 channels [106]. Notably, it is reported that camphor exhibits a bimodal concentration-dependent effect on TRPA1 channels: at high concentrations it blocked the channel [106,107], while at low concentrations it activated the receptor [107].

Asarum (genus) is commonly known as wild ginger due to its rhizomes and ginger root similarity in taste and smell. Most of the plants belonging to the genus Asarum contain aristolochic acid [108]. Aristolochic acid might activate TRPA1 channels as TRPA1 antagonists suppress the thermally dependent taste effect of aristolochic acid [109]. In addition, methyl eugenol was found to be the most abundant constituent of the essential oils of the majority of Asarum species [108]. It activated human TRPA1, exhibiting higher EC50 $(\sim 160 \mu \mathrm{M})$ than allyl isothiocyanate (EC50 $7 \mu \mathrm{M})$ [110].

Nigella damascena is an annual plant; its seeds are characterized by a strawberry flavor and unique aroma [111]. $\beta$-elemene (Figure 8) was found to be one of the main components in the essential oil of $N$. damascena seeds and one of the compounds responsible for its 
unique odor [111-113]. Computational studies predicted that $\beta$-elemene can activate TRPA1 [114].

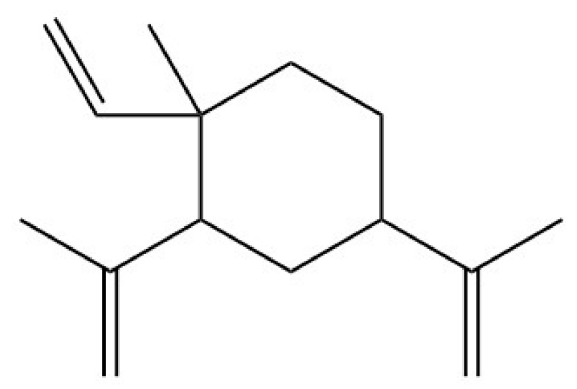

Figure 8. Chemical structure of $\beta$-elemene.

Cubebarum, known as tailed pepper, is mainly grown for its fruits and essential oil [115]. Many papers studied its chemical composition. Methyleugenol, eugenol, sabinene, eucalyptol, 4 -terpineol, $\beta$-pinene, camphor, elemene, $\alpha$-copaene, $\beta$-caryophyllene, epi-cubebol, cubebol and $\delta$-3-carene were reported as the main constituents isolated from the essential oils of the fruits of P. cubeba [115-118]). Eugenol, camphor and methyl eugenol were shown to be activators of TRPA1 [61-63,107,110], while the two latter compounds were found to activate TRPV1 $[64,65,106]$.

\section{Discussion}

TRP channels play numerous physiological roles, such as thermosensation, chemosensation, mechanosensation and osmosensation [119-124]. They are linked to several pathophysiological conditions, such as pain, cardiac hypertrophy, respiratory reflex hypersensitivity, cancer and genetic diseases [4,125-130]. For example, TRP melastatin 7 (TRPM7) channels has been shown to affect the viability of breast cancer cells via modulation of the cell cycle $[126,127]$. Furthermore, TRP canonical (TRPC) channels upregulation is involved in cardiac hypertrophy; its activation results in an increase in calcium. TRPC plays an important part in the regulation of the signaling cascades involved in cardiac hypertrophy $[125,128]$. TRPA1 and TRPV1 channels have well-established roles in pain and neurogenic inflammation [131,132]. In addition, non-neuronal TRPA1 and TRPV1 play a role in cardiovascular disease, immunity and other conditions [133]. Remarkably, it has been reported that almost all sensory neurons expressing TRPA1 (approximately 97\%) express TRPV1 [134]. Functional cross-desensitization has also been reported between the typical agonists of TRPA1 (allyl isothiocyanate) and TRPV1 (capsaicin) [135]. Furthermore, studies have shown that TRPA1 and TRPV1 can form a complex in the plasma membrane, and therefore influence each other's characteristics [136]. Thus, Fernandes et al. described TRPA1 and TRPV1 channels as "partners in crime" [133].

The mammalian respiratory tract is highly innervated with sensory fibers expressing TRPA1 and TRPV1. Sneezing occurs because of the activation of these sensory fibers (expressing TRPA1 and TRPV1) in the vagal sensory nerve terminals by noxious stimulants [4]. Signal transduction occurs by augmenting intracellular calcium concentrations and/or depolarizing membrane potentials $[137,138]$. It was found that there is an overexpression of TRPV1 in the nasal mucosa and augmented substance P levels in nasal secretions in idiopathic rhinitis patients [139].

Despite the fact that that only a few mixtures contained antagonists of TRPA1 and TRPV1 (which probably induced sneezing because of mechanical stimulation of the nasal receptors [1]), the majority of the constituents of the sneeze-inducing mixtures, used historically by physicians, are activators of TRPV1 and TRPA1 (Table 2). Figure 9 summarizes the structures of the constituents of the sneeze-inducing agents reported to activate TRPA1 and TRPV1. The big array of reported agonists supports the fact that these channels function as polymodal detectors $[140,141]$. 
Table 2. The constituents of sneeze-inducing remedies and their TRP modulatory activity.

\begin{tabular}{|c|c|c|}
\hline Sneeze-Inducing Remedies & Main Component & TRP Channel Agonist \\
\hline Cumini & Cuminaldehyde & TRPA1 \\
\hline Piperis & Piperine & TRPV1 and TRPA1 \\
\hline Castoreum & Acetophenone & TRPA1 \\
\hline Euphorbio & Resiniferatoxin & TRPV1 \\
\hline Ptarmice & trans-Pellitorine * & TRPV1 and TRPA1 (indirect) \\
\hline Nicotianae & Nicotine $^{* *}$ & TRPA1 \\
\hline $\begin{array}{l}\text { Ocimum basilicum/Cariophlli/ } \\
\text { Cubebarum }\end{array}$ & Eugenol & TRPA1 and TRPV1 \\
\hline Sinapis & Allyl isothiocyanate ** & TRPA1 and TRPV1 \\
\hline Urtica dioica & Carvacol & TRPA1 \\
\hline Cardamom & 1,8 -cineole $* *$ & TRPA1 \\
\hline \multirow{3}{*}{$\begin{array}{c}\text { Aframomum-Grana paradise/ } \\
\text { Ginger }\end{array}$} & 6-paradol & TRPV1 and TRPA1 \\
\hline & 6-gingerol & TRPV1 and TRPA1 \\
\hline & 6-shogaol & TRPV1 and TRPA1 \\
\hline \multirow{2}{*}{ Galangal } & $1^{\prime}$-acetoxychavicol acetate & TRPA1 \\
\hline & Galangan & TRPA1 \\
\hline Coriander & Linalool & TRPA1 \\
\hline Salt liquorice-Salzlakritz & $\begin{aligned} & \text { Glycyrrhizin } \rightarrow \text { glycyrrhetininc } \\
& \text { acid }\end{aligned}$ & TRPA1 \\
\hline Camphor/Cubebarum & Camphor ** & TRPA1 and TRPV1 \\
\hline Asarum & Aristolochic acid & TRPA1 \\
\hline Asarum/Cubebarum & Methyl eugenol & TRPA1 \\
\hline
\end{tabular}

TRPA1 and TRPV1 channels have six transmembrane (S1-S6) polypeptide subunits, permeable to cations via a pore formed by a tetramer assembly [142]. The hydrophobic pore region is located between S5 and S6 [143]. TRPA1 and TRPV1 contain ankyrin repeat motifs at the intracellular $N$-terminal; however, TRPA1 possess a remarkably high number of ankyrins [4]. TRPV1 and TRPA1 agonists both interact with binding sites to activate the channels.

TRPA1 has a very distinct mechanism of activation. Agonists activate TRPA1 via covalent modifications of the cysteine and lysine residues located in the ankyrin repeat motifs within the cytoplasmic $N$-terminus of the channel. Thus, TRPA1 activators can be categorized into thiol-reactive electrophilic compounds, which activate TRPA1 via covalent modification, and non-electrophilic compounds that activate TRPA1 via ligand binding [144,145]. Allyl isothiocyanate, an electrophile, was shown to form adduct with thiols and primary amines, proposing covalent modification. Notably, it was reported that thiol-reactive compounds of various structures activated TRPA1 via this mechanism [146]. Cuminal, acetophenone, acetoxychavicol, aristocholic acid, piperine, 6-paradol, 6-gingerol, 6-shogaol, pellitorine and camphor all potentially activate TRPA1 via covalent modification of the cysteine/lysine residues because of their electrophilic characteristics. This supports the finding that most of the noxious stimuli and electrophilic compounds activate TRPA1 via this distinctive mechanism, which explains its polymodal activity [122,147]. However, nicotine and carvacol have been shown to activate TRPA1 via non-covalent interaction with the channel $[55,78]$. The plausible mechanism of TRPA1 activation by linalool, 1,8-cineole, eugenol and methyl eugenol is via a similar non-covalent mechanism, as they are weak or non-electrophilic molecules. 


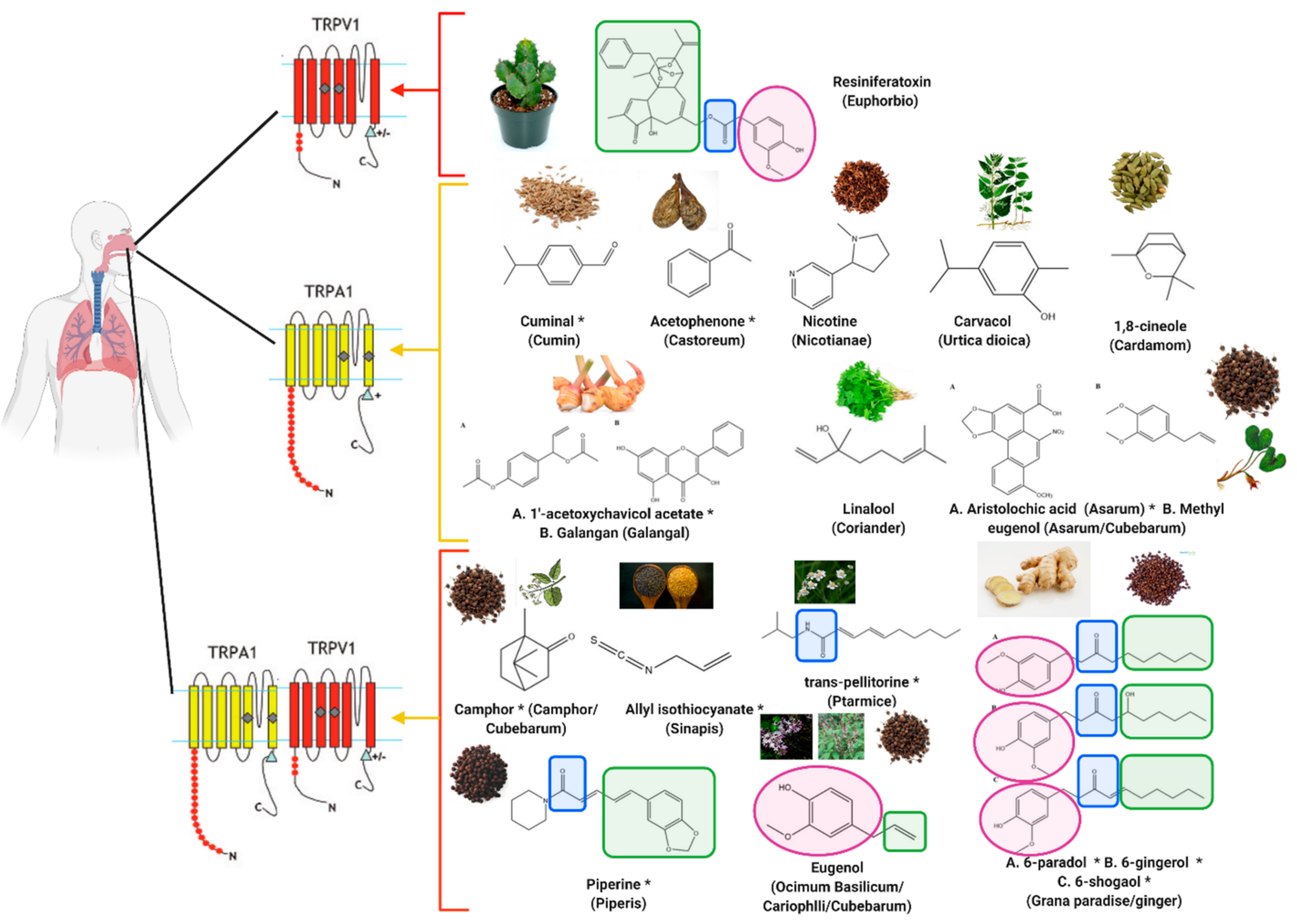

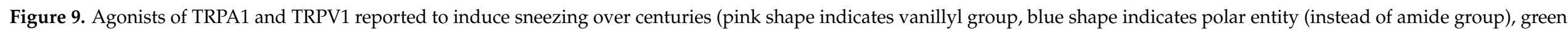

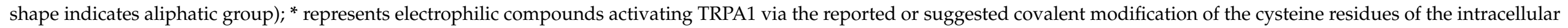
$N$-terminal. Generated by Biorender.com (accessed on 15 February 2021). 
Yang et al., 2015. showed that the aliphatic chain of capsaicin (Figure 10, a typical agonist of TRPV1) forms nonspecific Van der Waals interactions with the channel, contributing to binding affinity. On the other hand, the amide and vanillyl groups' interactions with T551 and E571, respectively, via hydrogen bonding, are essential for the specificity of ligand binding [148]. Resinferatoxin comprises a very similar pharmacophore to capsaicin, including vanillyl ester (similar to the amide group) and aliphatic groups, explaining its activity against only TRPV1. However, eugenol, 6-paradol, 6-gingerol and 6-shogaol maintained the vanillyl group, but not the amide, which might explain the additional activity against TRPA1. In the majority of these compounds, the amide group was replaced with polar entities and it was reported that this type of replacement reserves functionality, justifying their TRPV1 activity [149]. On the contrary, the lack of the vanillyl group in methyl eugenol led to a loss of TRPV1 activity reported with eugenol. Essentially, Del Prete et al. revealed an orthogonal structure-activity relationship for TRPV1 and TRPA1 binding, and proposed that agonists acting on both TRPA1 (non-electrophilic) and TRPV1 can be obtained by modifying the capsaicin pharmacophore [150].

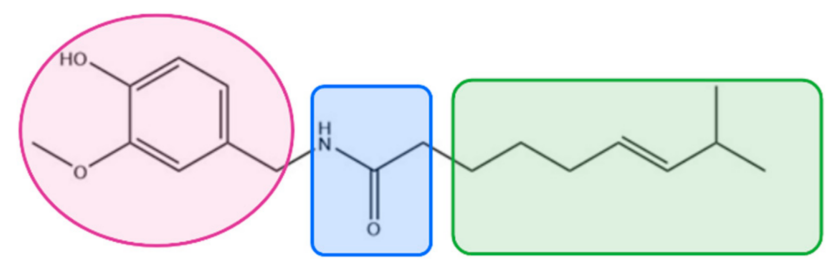

Figure 10. Chemical structure of capsaicin, a typical TRPV1 agonist (pink shape indicates vanillyl group, blue shape indicates amide group, green shape indicates aliphatic group).

Several binding sites have been reported for TRPV1 agonists. This might explain the reported TRPV1-inducing activity of camphor and allyl isothiocyanate, which lack the capsaicin pharmacophore. After interaction with residues in the S4-S5 linkers, capsaicin and resiniferatoxin twitch them away, thus opening the channel. It was found that the pore region is extremely flexible, and thus, every agonist might result in a different gating mechanism [143].

\section{Conclusions}

Historically, physicians commonly used various mixtures to induce sneezing; however, they were unaware and lacking knowledge of the molecular mechanism that explains this reflex. Today, after examining the constituents of these sneeze-inducing remedies, the majority are found to be agonists of TRPA1 and TRPV1 channels. This is in parallel with the role of TRPA1 and TRPV1 channels in sneezing. The paper sheds light on the potential area of research on TRP antagonism to treat sneezing. Additional investigations are required to explore the structure-activity relationship of these active ingredients.

Funding: This research received no external funding.

Conflicts of Interest: The authors declare no conflict of interest.

\section{References}

1. Nishino, T. Physiological and pathophysiological implications of upper airway reflexes in humans. Jpn. J. Physiol. 2000, 50, 3-14. [CrossRef] [PubMed]

2. Macron, J.M.; Wallois, F.; Duron, B. Influence of vagal afferents in the sneeze reflex in cats. Neurosci. Lett. 1994, 177, 79-82. [CrossRef]

3. Wallois, F.; Macron, J.M.; Duron, B. Activities of vagal receptors in the different phases of sneeze in cats. Respir. Physiol. 1995, 101, 239-255. [CrossRef]

4. Moran, M.M.; McAlexander, M.A.; Bíró, T.; Szallasi, A. Transient receptor potential channels as therapeutic targets. Nat. Rev. Drug Discov. 2011, 10, 601-620. [CrossRef]

5. Frias, B.; Merighi, A. Capsaicin, Nociception and Pain. Molecules 2016, 21, 797. [CrossRef] 
6. Takaya, J.; Mio, K.; Shiraishi, T.; Kurokawa, T.; Otsuka, S.; Mori, Y.; Uesugi, M. A Potent and Site-Selective Agonist of TRPA1. J. Am. Chem. Soc. 2015, 137, 15859-15864. [CrossRef]

7. Paulsen, C.E.; Armache, J.P.; Gao, Y.; Cheng, Y.; Julius, D. Structure of the TRPA1 ion channel suggests regulatory mechanisms. Nature 2015, 520, 511-517. [CrossRef]

8. Srinivasan, K. Biological Activities of Red Pepper (Capsicum annuum) and Its Pungent Principle Capsaicin: A Review. Crit. Rev. Food Sci. Nutr. 2016, 56, 1488-1500. [CrossRef]

9. Brubaker, A.P. The physiology of sneezing. J. Med. Assoc. 1919, 73, 585-587. [CrossRef]

10. Songu, M.; Cingi, C. Sneeze reflex: Facts and fiction. Ther. Adv. Respir. Dis. 2009, 3, 131-141. [CrossRef]

11. Askenasy, J.J. The history of sneezing. Postgrad Med. J. 1990, 66, 549-550. [CrossRef]

12. Justus Arnemann, L.A.K. Justus Arnemann's, Ehemaligen Professors der Medizin zu Göttingen, Chirurgische Arzneimittellehre; Vandenhoeck \& Ruprecht: Göttingen, Germany, 1813.

13. The London Medical Dictionary Vol1 | by Bartholomew Parr. Available online: https://chestofbooks.com/health/reference/ London-Medical-Dictionary/index.html (accessed on 1 February 2021).

14. Dioscorides, P.; Beck, L.Y. De Materia Medica; Olms-Weidmann: Hildesheim, Germany; New York, NY, USA, 2005.

15. Amida, A.D. Aetii Medici Graeci Contractae ex Veteribus Medicinae Tetrabiblos; Froben: Basel, Switzerland, 1549.

16. Pearn, J. Bernard de Gordon (fl. 1270-1330): Medieval physician and teacher. J. Med. Biogr. 2013, 21, 8-11. [CrossRef]

17. Leonhart, F. Opera: Dispensatorium Perfectum; Feyrabend et Huterus: Frankfurt am Main, Germany, 1567; Volume 1, pp. 399-400.

18. Di Matteo, B.; Tarabella, V.; Filardo, G.; Viganò, A.; Tomba, P.; Marcacci, M. The Renaissance and the universal surgeon: Giovanni Andrea Della Croce, a master of traumatology. Int. Orthop. 2013, 37, 2523-2528. [CrossRef]

19. Bencze, J. Franciscus Joel. Gyógyszerészet 1964, 386-388. [PubMed]

20. Dunn, P.M. Laurent Joubert of Montpellier (1529-82) and his Erreurs Populaires. Arch. Dis. Child. Fetal Neonatal Ed. 2000, 82, F255-F256. [CrossRef] [PubMed]

21. Encyclopedia.com. Available online: https://www.encyclopedia.com/religion/encyclopedias-almanacs-transcripts-and-maps / zacutus-lusitanus (accessed on 1 February 2021).

22. Chalmeteus, A. Enchiridion Chirvrgicom, Externorvm Morborvm Remedia ... Complectens. Quibus, Morbi Venerei Curandi Methodus; Andreas Wechelus: Frankfurt, Germany, 1560.

23. Martin Schoock. Available online: https://en.wikipedia.org/wiki/Martin_Schoock (accessed on 1 February 2021).

24. The Library. Available online: https:// mineralogicalrecord.com/libdetail.asp?id=1512 (accessed on 1 February 2021).

25. Justus Arnemann. Available online: https://de.wikipedia.org/wiki/Justus_Arnemann (accessed on 1 February 2021).

26. Bartholomew Parr. Available online: https://en.wikipedia.org/wiki/Bartholomew_Parr\#: :text=Dr\%20Bartholomew\%20Parr\% 20FRS\%20FRSE, British\%20physician\%20and\%20medical\%20author (accessed on 1 February 2021).

27. Tubbs, R.S.; Gribben, W.B.; Loukas, M.; Shoja, M.M.; Tubbs, K.O.; Oakes, W.J. Franz Kaspar Hesselbach (1759-1816): Anatomist and Surgeon. World J. Surg. 2008, 32, 2527-2529. [CrossRef]

28. Plantnet. Cuminum cyminum (Jansen, 1981). Available online: https://uses.plantnet-project.org/en/Cuminum_cyminum_ (Jansen,_1981) (accessed on 2 February 2021).

29. Sowbhagya, H.B. Chemistry, Technology, and Nutraceutical Functions of Cumin (cuminum cyminum L): An Overview. Crit. Rev. Food Sci. Nutr. 2013, 53, 1-10. [CrossRef]

30. Legrand, C.; Merlini, J.M.; de Senarclens-Bezençon, C.; Michlig, S. New natural agonists of the transient receptor potential Ankyrin 1 (TRPA1) channel. Sci. Rep. 2020, 10, 11238. [CrossRef]

31. Srinivasan, K. Black pepper and its pungent principle-piperine: A review of diverse physiological effects. Crit. Rev. Food Sci. Nutr. 2007, 47, 735-748. [CrossRef] [PubMed]

32. Lee, J.-G.; Chae, Y.; Shin, Y.; Kim, Y.-J. Chemical composition and antioxidant capacity of black pepper pericarp. Appl. Biol. Chem. 2020, 63, 35. [CrossRef]

33. Gevaert, T.; Vandepitte, J.; Hutchings, G.; Vriens, J.; Nilius, B.; De Ridder, D. TRPV1 is involved in stretch-evoked contractile changes in the rat autonomous bladder model: A study with piperine, a new TRPV1 agonist. Neurourol. Urodyn. 2007, 26, 440-450; discussion 451-443. [CrossRef]

34. Chen, C.Y.; Li, W.; Qu, K.P.; Chen, C.R. Piperine exerts anti-seizure effects via the TRPV1 receptor in mice. Eur. J. Pharmacol. 2013, 714, 288-294. [CrossRef]

35. Dong, Y.; Yin, Y.; Vu, S.; Yang, F.; Yarov-Yarovoy, V.; Tian, Y.; Zheng, J. A distinct structural mechanism underlies TRPV1 activation by piperine. Biochem. Biophys. Res. Commun. 2019, 516, 365-372. [CrossRef]

36. Yang, F.; Zheng, J. Understand spiciness: Mechanism of TRPV1 channel activation by capsaicin. Protein Cell 2017, 8, 169-177. [CrossRef]

37. Khom, S.; Strommer, B.; Schöffmann, A.; Hintersteiner, J.; Baburin, I.; Erker, T.; Schwarz, T.; Schwarzer, C.; Zaugg, J.; Hamburger, M.; et al. GABAA receptor modulation by piperine and a non-TRPV1 activating derivative. Biochem. Pharmacol. 2013, 85, 1827-1836. [CrossRef] [PubMed]

38. Okumura, Y.; Narukawa, M.; Iwasaki, Y.; Ishikawa, A.; Matsuda, H.; Yoshikawa, M.; Watanabe, T. Activation of TRPV1 and TRPA1 by black pepper components. Biosci. Biotechnol. Biochem. 2010, 74, 1068-1072. [CrossRef]

39. Watanabe, T.; Terada, Y. Food Compounds Activating Thermosensitive TRP Channels in Asian Herbal and Medicinal Foods. J. Nutr.Sci. Vitaminol. 2015, 61, S86-S88. [CrossRef] 
40. Jörg, J.C.G. Materialien zu einer künftigen heilmittellehre durch versuche der arzneyen an gesunden menschen gewonnen und gesammelt; C. Cnobloch: Leipzig, Germany, 1825; Volume 1.

41. Müller-Schwarze, D.; Houlihan, P.W. Pheromonal activity of single castoreum constituents in beaver, Castor canadensis. J. Chem. Ecol. 1991, 17, 715-734. [CrossRef] [PubMed]

42. Ma, W.; Chen, X.; Cerne, R.; Syed, S.K.; Ficorilli, J.V.; Cabrera, O.; Obukhov, A.G.; Efanov, A.M. Catechol estrogens stimulate insulin secretion in pancreatic $\beta$-cells via activation of the transient receptor potential A1 (TRPA1) channel. J. Biol. Chem. 2019, 294, 2935-2946. [CrossRef]

43. Lehmann, R.; Schöbel, N.; Hatt, H.; van Thriel, C. The involvement of TRP channels in sensory irritation: A mechanistic approach toward a better understanding of the biological effects of local irritants. Arch. Toxicol. 2016, 90, 1399-1413. [CrossRef]

44. Szallasi, A.; Blumberg, P.M. Resiniferatoxin, a phorbol-related diterpene, acts as an ultrapotent analog of capsaicin, the irritant constituent in red pepper. Neuroscience 1989, 30, 515-520. [CrossRef]

45. Darmani, N.A.; Henry, D.A.; Zhong, W.; Chebolu, S. Ultra-low doses of the transient receptor potential vanilloid 1 agonist, resiniferatoxin, prevents vomiting evoked by diverse emetogens in the least shrew (Cryptotis parva). Behav. Pharmacol. 2020, 31, 3-14. [CrossRef] [PubMed]

46. Stampanoni Bassi, M.; Gentile, A.; Iezzi, E.; Zagaglia, S.; Musella, A.; Simonelli, I.; Gilio, L.; Furlan, R.; Finardi, A.; Marfia, G.A.; et al. Transient Receptor Potential Vanilloid 1 Modulates Central Inflammation in Multiple Sclerosis. Front. Neurol. 2019, 10. [CrossRef]

47. Lee, Y.C.; Lu, S.C.; Hsieh, Y.L. Establishing a Mouse Model of a Pure Small Fiber Neuropathy with the Ultrapotent Agonist of Transient Receptor Potential Vanilloid Type 1. J. Vis. Exp. JoVE 2018, 56651. [CrossRef]

48. Veryser, L.; Taevernier, L.; Wynendaele, E.; Verheust, Y.; Dumoulin, A.; De Spiegeleer, B. N-alkylamide profiling of Achillea ptarmica and Achillea millefolium extracts by liquid and gas chromatography-mass spectrometry. J. Pharm. Anal. 2017, 7, 34-47. [CrossRef]

49. Althaus, J.B.; Kaiser, M.; Brun, R.; Schmidt, T.J. Antiprotozoal activity of Achillea ptarmica (Asteraceae) and its main alkamide constituents. Molecules 2014, 19, 6428-6438. [CrossRef]

50. Walker, J.; Ley, J.P.; Schwerzler, J.; Lieder, B.; Beltran, L.; Ziemba, P.M.; Hatt, H.; Hans, J.; Widder, S.; Krammer, G.E.; et al. Nonivamide, a capsaicin analogue, exhibits anti-inflammatory properties in peripheral blood mononuclear cells and U-937 macrophages. Mol. Nutr. Food Res. 2017, 61, 1600474. [CrossRef] [PubMed]

51. Lieder, B.; Zaunschirm, M.; Holik, A.K.; Ley, J.P.; Hans, J.; Krammer, G.E.; Somoza, V. The Alkamide trans-Pellitorine Targets PPAR $\gamma$ via TRPV1 and TRPA1 to Reduce Lipid Accumulation in Developing 3T3-L1 Adipocytes. Front. Pharm. 2017, 8, 316. [CrossRef]

52. Oláh, Z.; Rédei, D.; Pecze, L.; Vizler, C.; Jósvay, K.; Forgó, P.; Winter, Z.; Dombi, G.; Szakonyi, G.; Hohmann, J. Pellitorine, an extract of Tetradium daniellii, is an antagonist of the ion channel TRPV1. Phytomed. Int. J. Phytother. Phytopharmacol. 2017, 34, 44-49. [CrossRef]

53. Lundblad, L.; Lundberg, J.M.; Anggård, A. Local and systemic capsaicin pretreatment inhibits sneezing and the increase in nasal vascular permeability induced by certain chemical irritants. Naunyn-Schmiedeberg's Arch. Pharmacol. 1984, 326, $254-261$. [CrossRef] [PubMed]

54. Huang, H.-Y.; Hsieh, S.-H. Analyses of tobacco alkaloids by cation-selective exhaustive injection sweeping microemulsion electrokinetic chromatography. J. Chromatogr. A 2007, 1164, 313-319. [CrossRef]

55. Talavera, K.; Gees, M.; Karashima, Y.; Meseguer, V.M.; Vanoirbeek, J.A.J.; Damann, N.; Everaerts, W.; Benoit, M.; Janssens, A.; Vennekens, R.; et al. Nicotine activates the chemosensory cation channel TRPA1. Nat. Neurosci. 2009, 12, 1293-1299. [CrossRef]

56. Chung, S.; Baumlin, N.; Dennis, J.S.; Moore, R.; Salathe, S.F.; Whitney, P.L.; Sabater, J.; Abraham, W.M.; Kim, M.D.; Salathe, M. Electronic Cigarette Vapor with Nicotine Causes Airway Mucociliary Dysfunction Preferentially via TRPA1 Receptors. Am. J. Respir. Crit. Care Med. 2019, 200, 1134-1145. [CrossRef]

57. Kichko, T.I.; Lennerz, J.; Eberhardt, M.; Babes, R.M.; Neuhuber, W.; Kobal, G.; Reeh, P.W. Bimodal concentration-response of nicotine involves the nicotinic acetylcholine receptor, transient receptor potential vanilloid type 1, and transient receptor potential ankyrin 1 channels in mouse trachea and sensory neurons. J. Pharmacol. Exp. Ther. 2013, 347, 529-539. [CrossRef] [PubMed]

58. Liu, L.; Zhu, W.; Zhang, Z.-S.; Yang, T.; Grant, A.; Oxford, G.; Simon, S.A. Nicotine Inhibits Voltage-Dependent Sodium Channels and Sensitizes Vanilloid Receptors. J. Neurophysiol. 2004, 91, 1482-1491. [CrossRef] [PubMed]

59. Joshi, R.K. Chemical composition and antimicrobial activity of the essential oil of Ocimum basilicum L. (sweet basil) from Western Ghats of North West Karnataka, India. Anc. Sci. Life 2014, 33, 151-156. [CrossRef] [PubMed]

60. Yan, H.; Ma, Y.; Han, B. Rapid detection of the component contents in caryophylli flos by a handheld near infrared spectrometer based on digital light processing technology. J. Near Infrared Spectrosc. 2018, 26, 389-397. [CrossRef]

61. Bandell, M.; Story, G.M.; Hwang, S.W.; Viswanath, V.; Eid, S.R.; Petrus, M.J.; Earley, T.J.; Patapoutian, A. Noxious Cold Ion Channel TRPA1 Is Activated by Pungent Compounds and Bradykinin. Neuron 2004, 41, 849-857. [CrossRef]

62. Chung, G.; Im, S.T.; Kim, Y.H.; Jung, S.J.; Rhyu, M.R.; Oh, S.B. Activation of transient receptor potential ankyrin 1 by eugenol. Neuroscience 2014, 261, 153-160. [CrossRef]

63. Inoue, M.; Fujita, T.; Goto, M.; Kumamoto, E. Presynaptic enhancement by eugenol of spontaneous excitatory transmission in rat spinal substantia gelatinosa neurons is mediated by transient receptor potential A1 channels. Neuroscience 2012, 210 , 403-415. [CrossRef] 
64. Yang, B.H.; Piao, Z.G.; Kim, Y.B.; Lee, C.H.; Lee, J.K.; Park, K.; Kim, J.S.; Oh, S.B. Activation of Vanilloid Receptor 1 (VR1) by Eugenol. J. Dent. Res. 2003, 82, 781-785. [CrossRef]

65. Park, C.K.; Kim, K.; Jung, S.J.; Kim, M.J.; Ahn, D.K.; Hong, S.D.; Kim, J.S.; Oh, S.B. Molecular mechanism for local anesthetic action of eugenol in the rat trigeminal system. Pain 2009, 144, 84-94. [CrossRef]

66. Boscaro, V.; Boffa, L.; Binello, A.; Amisano, G.; Fornasero, S.; Cravotto, G.; Gallicchio, M. Antiproliferative, Proapoptotic, Antioxidant and Antimicrobial Effects of Sinapis nigra L. and Sinapis alba L. Extracts. Molecules 2018, 23, 3004. [CrossRef]

67. Eib, S.; Schneider, D.J.; Hensel, O.; Seuß-Baum, I. Relationship between mustard pungency and allyl-isothiocyanate content: A comparison of sensory and chemical evaluations. J. Food Sci. 2020, 85, 2728-2736. [CrossRef]

68. Ghawi, S.K.; Methven, L.; Niranjan, K. The potential to intensify sulforaphane formation in cooked broccoli (Brassica oleracea var. italica) using mustard seeds (Sinapis alba). Food Chem. 2013, 138, 1734-1741. [CrossRef]

69. Peng, C.; Zhao, S.Q.; Zhang, J.; Huang, G.Y.; Chen, L.Y.; Zhao, F.Y. Chemical composition, antimicrobial property and microencapsulation of Mustard (Sinapis alba) seed essential oil by complex coacervation. Food Chem. 2014, 165, 560-568. [CrossRef]

70. Bautista, D.M.; Jordt, S.-E.; Nikai, T.; Tsuruda, P.R.; Read, A.J.; Poblete, J.; Yamoah, E.N.; Basbaum, A.I.; Julius, D. TRPA1 Mediates the Inflammatory Actions of Environmental Irritants and Proalgesic Agents. Cell 2006, 124, 1269-1282. [CrossRef]

71. Everaerts, W.; Gees, M.; Alpizar, Y.A.; Farre, R.; Leten, C.; Apetrei, A.; Dewachter, I.; van Leuven, F.; Vennekens, R.; De Ridder, D.; et al. The Capsaicin Receptor TRPV1 Is a Crucial Mediator of the Noxious Effects of Mustard Oil. Curr. Biol. 2011, $21,316-321$. [CrossRef]

72. Mori, N.; Kawabata, F.; Matsumura, S.; Hosokawa, H.; Kobayashi, S.; Inoue, K.; Fushiki, T. Intragastric administration of allyl isothiocyanate increases carbohydrate oxidation via TRPV1 but not TRPA1 in mice. Am. J. Physiol. Regul. Integr. Comp. Physiol. 2011, 300, R1494-R1505. [CrossRef]

73. Mori, N.; Kurata, M.; Yamazaki, H.; Matsumura, S.; Hashimoto, T.; Kanazawa, K.; Nadamoto, T.; Inoue, K.; Fushiki, T. Allyl isothiocyanate increases carbohydrate oxidation through enhancing insulin secretion by TRPV1. Biosci. Biotechnol. Biochem. 2018, 82, 698-708. [CrossRef]

74. Gül, S.; Demirci, B.; Başer, K.H.; Akpulat, H.A.; Aksu, P. Chemical composition and in vitro cytotoxic, genotoxic effects of essential oil from Urtica dioica L. Bull. Environ. Contam. Toxicol. 2012, 88, 666-671. [CrossRef] [PubMed]

75. Xu, H.; Delling, M.; Jun, J.C.; Clapham, D.E. Oregano, thyme and clove-derived flavors and skin sensitizers activate specific TRP channels. Nat. Neurosci. 2006, 9, 628-635. [CrossRef]

76. Yamada, T.; Ueda, T.; Ugawa, S.; Ishida, Y.; Imayasu, M.; Koyama, S.; Shimada, S. Functional expression of transient receptor potential vanilloid 3 (TRPV3) in corneal epithelial cells: Involvement in thermosensation and wound healing. Exp. Eye Res. 2010, 90, 121-129. [CrossRef]

77. Alvarenga, E.M.; Souza, L.K.M.; Araújo, T.S.L.; Nogueira, K.M.; Sousa, F.B.M.; Araújo, A.R.; Martins, C.S.; Pacífico, D.M.; de Brito, G.A.; Souza, E.P.; et al. Carvacrol reduces irinotecan-induced intestinal mucositis through inhibition of inflammation and oxidative damage via TRPA1 receptor activation. Chem. Biol. Interact. 2016, 260, 129-140. [CrossRef] [PubMed]

78. Mukaiyama, M.; Usui, T.; Nagumo, Y. Non-electrophilic TRPA1 agonists, menthol, carvacrol and clotrimazole, open epithelial tight junctions via TRPA1 activation. J. Biochem. 2020, 168, 407-415. [CrossRef]

79. Xiao, S.; Zhang, Y.; Song, P.; Xie, J.; Pang, G. The investigation of allosteric regulation mechanism of analgesic effect using SD rat taste bud tissue biosensor. Biosens. Bioelectron. 2019, 126, 815-823. [CrossRef]

80. Noumi, E.; Snoussi, M.; Alreshidi, M.M.; Rekha, P.D.; Saptami, K.; Caputo, L.; De Martino, L.; Souza, L.F.; Msaada, K.; Mancini, E.; et al. Chemical and Biological Evaluation of Essential Oils from Cardamom Species. Molecules 2018, 23, 2818. [CrossRef] [PubMed]

81. Jiang, C.Y.; Wang, C.; Xu, N.X.; Fujita, T.; Murata, Y.; Kumamoto, E. 1,8- and 1,4-cineole enhance spontaneous excitatory transmission by activating different types of transient receptor potential channels in the rat spinal substantia gelatinosa. $J$. Neurochem. 2016, 136, 764-777. [CrossRef]

82. Takaishi, M.; Fujita, F.; Uchida, K.; Yamamoto, S.; Sawada Shimizu, M.; Hatai Uotsu, C.; Shimizu, M.; Tominaga, M. 1,8-cineole, a TRPM8 agonist, is a novel natural antagonist of human TRPA1. Mol. Pain 2012, 8, 86. [CrossRef]

83. Karashima, Y.; Damann, N.; Prenen, J.; Talavera, K.; Segal, A.; Voets, T.; Nilius, B. Bimodal Action of Menthol on the Transient Receptor Potential Channel TRPA1. J. Neurosci. 2007, 27, 9874-9884. [CrossRef] [PubMed]

84. Deng, X.; Zhang, S.; Wu, J.; Sun, X.; Shen, Z.; Dong, J.; Huang, J. Promotion of Mitochondrial Biogenesis via Activation of AMPK-PGC1 $\alpha$ Signaling Pathway by Ginger (Zingiber officinale Roscoe) Extract, and Its Major Active Component 6-Gingerol. J. Food Sci. 2019, 84, 2101-2111. [CrossRef]

85. Prasad, S.; Tyagi, A.K. Ginger and its constituents: Role in prevention and treatment of gastrointestinal cancer. Gastroenterol. Res. Pract. 2015, 2015, 142979. [CrossRef]

86. Sugita, J.; Yoneshiro, T.; Hatano, T.; Aita, S.; Ikemoto, T.; Uchiwa, H.; Iwanaga, T.; Kameya, T.; Kawai, Y.; Saito, M. Grains of paradise (Aframomum melegueta) extract activates brown adipose tissue and increases whole-body energy expenditure in men. Br. J. Nutr. 2013, 110, 733-738. [CrossRef]

87. Yoshitomi, T.; Oshima, N.; Goto, Y.; Nakamori, S.; Wakana, D.; Anjiki, N.; Sugimura, K.; Kawano, N.; Fuchino, H.; Iida, O.; et al. Construction of Prediction Models for the Transient Receptor Potential Vanilloid Subtype 1 (TRPV1)-Stimulating Activity of Ginger and Processed Ginger Based on LC-HRMS Data and PLS Regression Analyses. J. Agric. Food Chem. 2017, 65, 3581-3588. [CrossRef] 
88. Riera, C.E.; Menozzi-Smarrito, C.; Affolter, M.; Michlig, S.; Munari, C.; Robert, F.; Vogel, H.; Simon, S.A.; le Coutre, J. Compounds from Sichuan and Melegueta peppers activate, covalently and non-covalently, TRPA1 and TRPV1 channels. Br. J. Pharmacol. 2009, 157, 1398-1409. [CrossRef]

89. Kim, Y.-S.; Hong, C.S.; Lee, S.W.; Nam, J.H.; Kim, B.J. Effects of ginger and its pungent constituents on transient receptor potential channels. Int. J. Mol. Med. 2016, 38, 1905-1914. [CrossRef]

90. Narukawa, M.; Koizumi, K.; Iwasaki, Y.; Kubota, K.; Watanabe, T. Galangal pungent component, 1'-acetoxychavicol acetate, activates TRPA1. Biosci. Biotechnol. Biochem. 2010, 74, 1694-1696. [CrossRef]

91. Basri, A.M.; Taha, H.; Ahmad, N. A Review on the Pharmacological Activities and Phytochemicals of Alpinia officinarum (Galangal) Extracts Derived from Bioassay-Guided Fractionation and Isolation. Pharmacogn. Rev. 2017, 11, 43-56. [CrossRef]

92. Nakamura, T.; Miyoshi, N.; Ishii, T.; Nishikawa, M.; Ikushiro, S.; Watanabe, T. Activation of transient receptor potential ankyrin 1 by quercetin and its analogs. Biosci. Biotechnol. Biochem. 2016, 80, 949-954. [CrossRef]

93. Wong, K.C.; Ong, K.S.; Lim, C.L. Compositon of the essential oil of rhizomes of kaempferia galanga L. Flavour Fragr. J. 1992, 7, 263-266. [CrossRef]

94. Gil, A.; De La Fuente, E.B.; Lenardis, A.E.; López Pereira, M.; Suárez, S.A.; Bandoni, A.; Van Baren, C.; Di Leo Lira, P.; Ghersa, C.M. Coriander essential oil composition from two genotypes grown in different environmental conditions. J. Agric. Food Chem. 2002, 50, 2870-2877. [CrossRef]

95. Caputo, L.; Piccialli, I.; Ciccone, R.; de Caprariis, P.; Massa, A.; De Feo, V.; Pannaccione, A. Lavender and coriander essential oils and their main component linalool exert a protective effect against amyloid- $\beta$ neurotoxicity. Phytother. Res. PTR 2020, 35, 486-493. [CrossRef]

96. Fothergill, L.J.; Callaghan, B.; Rivera, L.R.; Lieu, T.; Poole, D.P.; Cho, H.J.; Bravo, D.M.; Furness, J.B. Effects of Food Components That Activate TRPA1 Receptors on Mucosal Ion Transport in the Mouse Intestine. Nutrients 2016, 8, 623. [CrossRef]

97. Shah, S.L.; Wahid, F.; Khan, N.; Farooq, U.; Shah, A.J.; Tareen, S.; Ahmad, F.; Khan, T. Inhibitory Effects of Glycyrrhiza glabra and Its Major Constituent Glycyrrhizin on Inflammation-Associated Corneal Neovascularization. Evid. Based Complement. Altern. Med. eCAM 2018, 2018, 8438101. [CrossRef]

98. Kurahara, L.H.; Hiraishi, K.; Hu, Y.; Koga, K.; Onitsuka, M.; Doi, M.; Aoyagi, K.; Takedatsu, H.; Kojima, D.; Fujihara, Y.; et al. Activation of Myofibroblast TRPA1 by Steroids and Pirfenidone Ameliorates Fibrosis in Experimental Crohn's Disease. Cell. Mol. Gastroenterol. Hepatol. 2018, 5, 299-318. [CrossRef]

99. Tu, J.; Guo, Y.; Hong, W.; Fang, Y.; Han, D.; Zhang, P.; Wang, X.; Körner, H.; Wei, W. The Regulatory Effects of Paeoniflorin and Its Derivative Paeoniflorin-6'-O-Benzene Sulfonate CP-25 on Inflammation and Immune Diseases. Front. Pharmacol. 2019, 10, 57. [CrossRef]

100. Yan, Z.; Xie, L.; Tian, Y.; Li, M.; Ni, J.; Zhang, Y.; Niu, L. Insights into the Phytochemical Composition and Bioactivities of Seeds from Wild Peony Species. Plants 2020, 9, 729. [CrossRef] [PubMed]

101. Yin, N.; Gao, Q.; Tao, W.; Chen, J.; Bi, J.; Ding, F.; Wang, Z. Paeoniflorin relieves LPS-induced inflammatory pain in mice by inhibiting NLRP3 inflammasome activation via transient receptor potential vanilloid 1. J. Leukoc. Biol. 2020, 108, $229-241$. [CrossRef]

102. Chen, Y.; Zhou, C.; Ge, Z.; Liu, Y.; Liu, Y.; Feng, W.; Li, S.; Chen, G.; Wei, T. Composition and potential anticancer activities of essential oils obtained from myrrh and frankincense. Oncol. Lett. 2013, 6, 1140-1146. [CrossRef]

103. Morteza-Semnani, K.; Saeedi, M. Constituents of the Essential Oil of Commiphora myrrha (Nees) Engl. var. molmol. J. Essent. Oil Res. 2003, 15, 50-51. [CrossRef]

104. Hu, D.; Wang, C.; Li, F.; Su, S.; Yang, N.; Yang, Y.; Zhu, C.; Shi, H.; Yu, L.; Geng, X.; et al. A Combined Water Extract of Frankincense and Myrrh Alleviates Neuropathic Pain in Mice via Modulation of TRPV1. Neural Plast. 2017, $2017,3710821$. [CrossRef]

105. Chen, W.; Vermaak, I.; Viljoen, A. Camphor-a fumigant during the Black Death and a coveted fragrant wood in ancient Egypt and Babylon-A review. Molecules 2013, 18, 5434-5454. [CrossRef]

106. Xu, H.; Blair, N.T.; Clapham, D.E. Camphor activates and strongly desensitizes the transient receptor potential vanilloid subtype 1 channel in a vanilloid-independent mechanism. J. Neurosci. Off. J. Soc. Neurosci. 2005, 25, 8924-8937. [CrossRef]

107. Alpizar, Y.A.; Gees, M.; Sanchez, A.; Apetrei, A.; Voets, T.; Nilius, B.; Talavera, K. Bimodal effects of cinnamaldehyde and camphor on mouse TRPA1. Pflüg. Arch. Eur. J. Physiol. 2013, 465, 853-864. [CrossRef]

108. Antsyshkina, A.M. The Genus Asarum L.: A Phytochemical and Ethnopharmacological Review. Syst. Rev. Pharm. 2020, 11, 472-502. [CrossRef]

109. Afroz, A.; Howlett, N.; Shukla, A.; Ahmad, F.; Batista, E.; Bedard, K.; Payne, S.; Morton, B.; Mansfield, J.H.; Glendinning, J.I. Gustatory receptor neurons in Manduca sexta contain a TrpA1-dependent signaling pathway that integrates taste and temperature. Chem. Senses 2013, 38, 605-617. [CrossRef]

110. Moon, H.; Kim, M.J.; Son, H.J.; Kweon, H.J.; Kim, J.T.; Kim, Y.; Shim, J.; Suh, B.C.; Rhyu, M.R. Five hTRPA1 Agonists Found in Indigenous Korean Mint, Agastache rugosa. PLoS ONE 2015, 10, e0127060. [CrossRef]

111. Fico, G.; Bader, A.; Flamini, G.; Cioni, P.L.; Morelli, I. Essential Oil of Nigella damascena L. (Ranunculaceae) Seeds. J. Essent. Oil Res. 2003, 15, 57-58. [CrossRef]

112. Rchid, H.; Nmila, R.; Bessière, J.M.; Sauvaire, Y.; Chokaïri, M. Volatile Components of Nigella damascena L. and Nigella sativa L. Seeds. J. Essent. Oil Res. 2004, 16, 585-587. [CrossRef] 
113. Moretti, A.; D'Antuono, L.F.; Elementi, S. Essential Oils of Nigella sativa L. and Nigella damascena L. Seed. J. Essent. Oil Res. 2004, 16, 182-183. [CrossRef]

114. Aikkal, R. Phytochemical analysis, carminative, enzyme inhibitor, and anticancer activities of beta-elemene. Retrieved March 2016. [CrossRef]

115. Andriana, Y.; Xuan, T.D.; Quy, T.N.; Tran, H.D.; Le, Q.T. Biological Activities and Chemical Constituents of Essential Oils from Piper cubeba Bojer and Piper nigrum L. Molecules 2019, 24, 1876. [CrossRef]

116. Alminderej, F.; Bakari, S.; Almundarij, T.I.; Snoussi, M.; Aouadi, K.; Kadri, A. Antioxidant Activities of a New Chemotype of Piper cubeba L. Fruit Essential Oil (Methyleugenol/Eugenol): In Silico Molecular Docking and ADMET Studies. Plants 2020, 9 , 1534. [CrossRef] [PubMed]

117. Magalhães, L.G.; de Souza, J.M.; Wakabayashi, K.A.; Laurentiz Rda, S.; Vinhólis, A.H.; Rezende, K.C.; Simaro, G.V.; Bastos, J.K.; Rodrigues, V.; Esperandim, V.R.; et al. In vitro efficacy of the essential oil of Piper cubeba L. (Piperaceae) against Schistosoma mansoni. Parasitol. Res. 2012, 110, 1747-1754. [CrossRef]

118. Bos, R.; Woerdenbag, H.; Kayser, O.; Quax, W.; Ruslan, K.; Elfami. Essential Oil Constituents of Piper cubeba L. fils. from Indonesia. J. Essent. Oil Res. 2007, 19, 14-17. [CrossRef]

119. Vriens, J.; Watanabe, H.; Janssens, A.; Droogmans, G.; Voets, T.; Nilius, B. Cell swelling, heat, and chemical agonists use distinct pathways for the activation of the cation channel TRPV4. Proc. Natl. Acad. Sci. USA 2004, 101, 396-401. [CrossRef]

120. Kwan, K.Y.; Allchorne, A.J.; Vollrath, M.A.; Christensen, A.P.; Zhang, D.S.; Woolf, C.J.; Corey, D.P. TRPA1 contributes to cold, mechanical, and chemical nociception but is not essential for hair-cell transduction. Neuron 2006, 50, 277-289. [CrossRef]

121. Bautista, D.M.; Siemens, J.; Glazer, J.M.; Tsuruda, P.R.; Basbaum, A.I.; Stucky, C.L.; Jordt, S.E.; Julius, D. The menthol receptor TRPM8 is the principal detector of environmental cold. Nature 2007, 448, 204-208. [CrossRef] [PubMed]

122. Bessac, B.F.; Jordt, S.E. Breathtaking TRP channels: TRPA1 and TRPV1 in airway chemosensation and reflex control. Physiology 2008, 23, 360-370. [CrossRef] [PubMed]

123. Christensen, A.P.; Corey, D.P. TRP channels in mechanosensation: Direct or indirect activation? Nat. Rev. Neurosci. 2007, 8 , 510-521. [CrossRef] [PubMed]

124. Wang, H.; Siemens, J. TRP ion channels in thermosensation, thermoregulation and metabolism. Temperature 2015, 2, $178-187$. [CrossRef]

125. Nishida, M.; Kurose, H. Roles of TRP channels in the development of cardiac hypertrophy. Naunyn-Schmiedeberg's Arch. pharmacol. 2008, 378, 395-406. [CrossRef]

126. Liu, H.; Dilger, J.P.; Lin, J. The Role of Transient Receptor Potential Melastatin 7 (TRPM7) in Cell Viability: A Potential Target to Suppress Breast Cancer Cell Cycle. Cancers 2020, 12, 131. [CrossRef] [PubMed]

127. Liu, H.; Dilger, J.P.; Lin, J. Lidocaine Suppresses Viability and Migration of Human Breast Cancer Cells: TRPM7 as a Target for Some Breast Cancer Cell Lines. Cancers 2021, 13, 234. [CrossRef]

128. Ohba, T.; Watanabe, H.; Murakami, M.; Takahashi, Y.; Iino, K.; Kuromitsu, S.; Mori, Y.; Ono, K.; Iijima, T.; Ito, H. Upregulation of TRPC1 in the development of cardiac hypertrophy. J. Mol. Cell. Cardiol. 2007, 42, 498-507. [CrossRef] [PubMed]

129. Nassini, R.; Materazzi, S.; Benemei, S.; Geppetti, P. The TRPA1 channel in inflammatory and neuropathic pain and migraine. Rev. Physiol. Biochem. Pharmacol. 2014, 167, 1-43. [CrossRef] [PubMed]

130. Kang, S.S.; Shin, S.H.; Auh, C.K.; Chun, J. Human skeletal dysplasia caused by a constitutive activated transient receptor potential vanilloid 4 (TRPV4) cation channel mutation. Exp. Mol. Med. 2012, 44, 707-722. [CrossRef]

131. Bevan, S.; Andersson, D.A. TRP channel antagonists for pain-opportunities beyond TRPV1. Curr. Opin. Investig. Drugs 2009, 10, 655-663.

132. Gouin, O.; L’Herondelle, K.; Lebonvallet, N.; Le Gall-Ianotto, C.; Sakka, M.; Buhé, V.; Plée-Gautier, E.; Carré, J.L.; Lefeuvre, L.; Misery, L.; et al. TRPV1 and TRPA1 in cutaneous neurogenic and chronic inflammation: Pro-inflammatory response induced by their activation and their sensitization. Protein Cell 2017, 8, 644-661. [CrossRef]

133. Fernandes, E.; Fernandes, M.; Keeble, J. The functions of TRPA1 and TRPV1: Moving away from sensory nerves. Br. J. Pharmacol. 2012, 166, 510-521. [CrossRef]

134. Story, G.M.; Peier, A.M.; Reeve, A.J.; Eid, S.R.; Mosbacher, J.; Hricik, T.R.; Earley, T.J.; Hergarden, A.C.; Andersson, D.A.; Hwang, S.W.; et al. ANKTM1, a TRP-like channel expressed in nociceptive neurons, is activated by cold temperatures. Cell 2003, 112, 819-829. [CrossRef]

135. Mihara, S.; Shibamoto, T. The role of flavor and fragrance chemicals in TRPA1 (transient receptor potential cation channel, member A1) activity associated with allergies. Allergy Asthma Clin. Immunol. Off. J. Can. Soc. Allergy Clin. Immunol. 2015, 11, 11. [CrossRef] [PubMed]

136. Staruschenko, A.; Jeske, N.A.; Akopian, A.N. Contribution of TRPV1-TRPA1 Interaction to the Single Channel Properties of the TRPA1 Channel. J. Biol. Chem. 2010, 285, 15167-15177. [CrossRef] [PubMed]

137. Samanta, A.; Hughes, T.E.T.; Moiseenkova-Bell, V.Y. Transient Receptor Potential (TRP) Channels. Sub-cell. Biochem. 2018, 87, 141-165. [CrossRef]

138. Aloum, L.; Alefishat, E.; Adem, A.; Petroianu, G. Ionone Is More than a Violet's Fragrance: A Review. Molecules 2020, $25,5822$. [CrossRef] [PubMed] 
139. Van Gerven, L.; Alpizar, Y.A.; Wouters, M.M.; Hox, V.; Hauben, E.; Jorissen, M.; Boeckxstaens, G.; Talavera, K.; Hellings, P.W. Capsaicin treatment reduces nasal hyperreactivity and transient receptor potential cation channel subfamily V, receptor 1 (TRPV1) overexpression in patients with idiopathic rhinitis. J. Allergy Clin. Immunol. 2014, 133, 1332-1339. [CrossRef]

140. Caterina, M.J.; Park, U. Chapter 4 TRPV1: A Polymodal Sensor in the Nociceptor Terminal. In Current Topics in Membranes; Academic Press: Cambridge, MA, USA, 2006; Volume 57, pp. 113-150.

141. Bang, S.; Hwang, S.W. Polymodal Ligand Sensitivity of TRPA1 and Its Modes of Interactions. J. Gen. Physiol. 2009, 133, 257-262. [CrossRef] [PubMed]

142. Bernardini, M.; Fiorio Pla, A.; Prevarskaya, N.; Gkika, D. Human transient receptor potential (TRP) channel expression profiling in carcinogenesis. Int. J. Dev. Biol. 2015, 59, 399-406. [CrossRef]

143. Benítez-Angeles, M.; Morales-Lázaro, S.L.; Juárez-González, E.; Rosenbaum, T. TRPV1: Structure, Endogenous Agonists, and Mechanisms. Int. J. Mol. Sci. 2020, 21, 3421. [CrossRef] [PubMed]

144. Chernov-Rogan, T.; Gianti, E.; Liu, C.; Villemure, E.; Cridland, A.P.; Hu, X.; Ballini, E.; Lange, W.; Deisemann, H.; Li, T.; et al. TRPA1 modulation by piperidine carboxamides suggests an evolutionarily conserved binding site and gating mechanism. Proc. Natl. Acad. Sci. USA 2019, 116, 26008-26019. [CrossRef] [PubMed]

145. Meents, J.E.; Ciotu, C.I.; Fischer, M.J.M. TRPA1: A molecular view. J. Neurophysiol. 2019, 121, 427-443. [CrossRef]

146. Hinman, A.; Chuang, H.-h.; Bautista, D.M.; Julius, D. TRP channel activation by reversible covalent modification. Proc. Natl. Acad. Sci. USA 2006, 103, 19564-19568. [CrossRef] [PubMed]

147. Macpherson, L.J.; Dubin, A.E.; Evans, M.J.; Marr, F.; Schultz, P.G.; Cravatt, B.F.; Patapoutian, A. Noxious compounds activate TRPA1 ion channels through covalent modification of cysteines. Nature 2007, 445, 541-545. [CrossRef] [PubMed]

148. Yang, F.; Xiao, X.; Cheng, W.; Yang, W.; Yu, P.; Song, Z.; Yarov-Yarovoy, V.; Zheng, J. Structural mechanism underlying capsaicin binding and activation of the TRPV1 ion channel. Nat. Chem. Biol. 2015, 11, 518-524. [CrossRef] [PubMed]

149. Elokely, K.; Velisetty, P.; Delemotte, L.; Palovcak, E.; Klein, M.L.; Rohacs, T.; Carnevale, V. Understanding TRPV1 activation by ligands: Insights from the binding modes of capsaicin and resiniferatoxin. Proc. Natl. Acad. Sci. USA 2016, 113, E137-E145. [CrossRef] [PubMed]

150. Del Prete, D.; Caprioglio, D.; Appendino, G.; Minassi, A.; Schiano-Moriello, A.; Di Marzo, V.; De Petrocellis, L. Discovery of non-electrophilic capsaicinoid-type TRPA1 ligands. Bioorg. Med. Chem. Lett. 2015, 25, 1009-1011. [CrossRef] [PubMed] 